\title{
Михаил Михайлович Глухов (некролог)
}

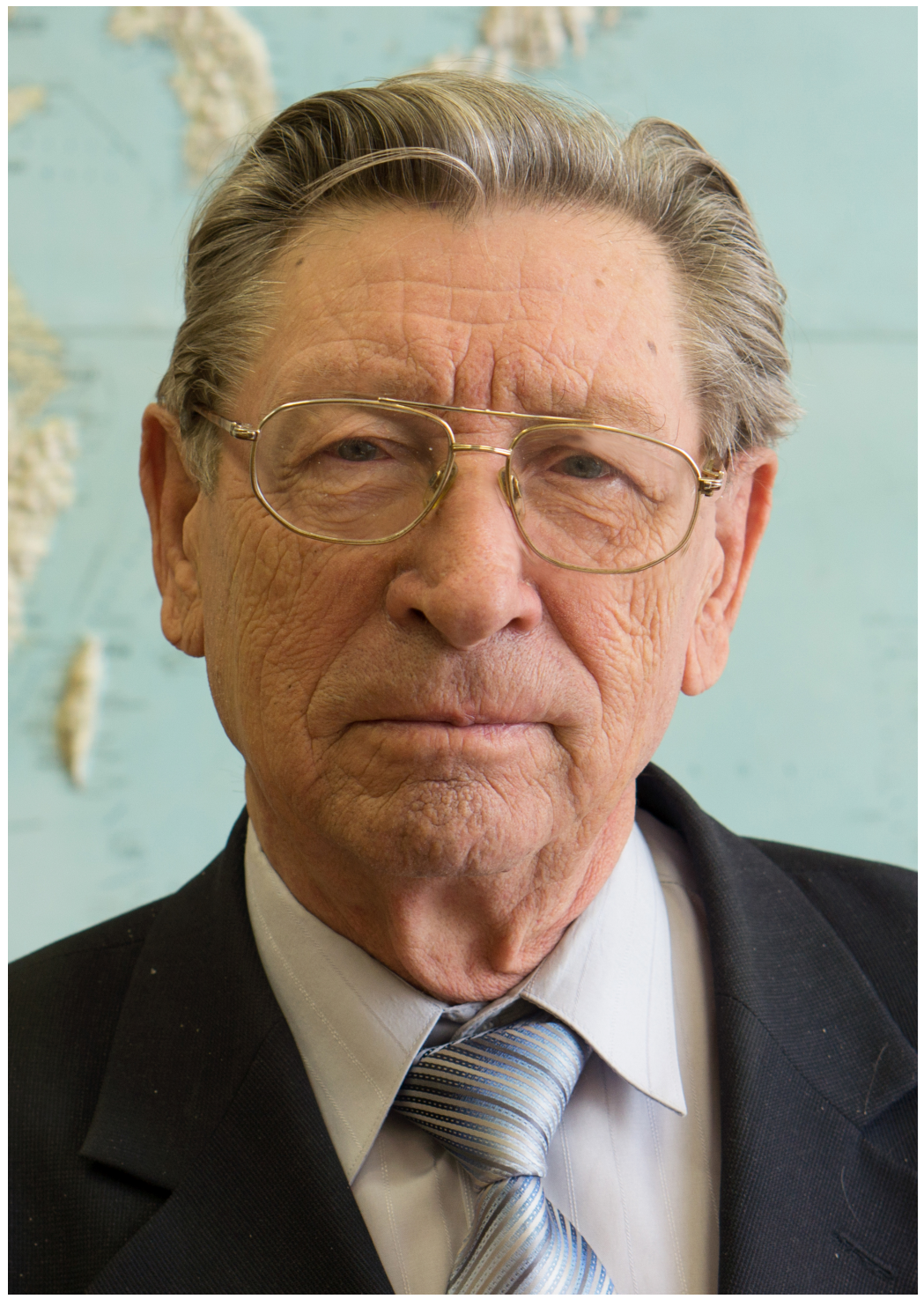

20 ноября 1930 г. - 9 декабря 2018 г.

Ушёл из жизни замечательный человек, выдающийся математик, действительный член академии криптографии РФ, профессор Михаил Михайлович ГЛУХОВ.

Результаты М. М. Глухова по алгебре, по теории чисел, а также по их приложениям внесли замечательный вклад в развитие как теоретических, так и практических разделов математики. Его многогранная научно-организаторская деятельность и редакторская работа в журналах "Дискретная математика"и "Чебышевский сборник" всегда способствовали углублению отечественных научных исследований и притоку молодых научных кадров. 